\title{
Treatment of peri-implant soft tissue defects: a narrative review
}

\section{Fausto FRIZZERA ${ }^{(a)}$ \\ Guilherme José Pimentel Lopes de OLIVEIRA $^{(b)}$}

Jamil Awad SHIBLI(c)

Kely Cristina de MORAES(d) Eloísa Boeck MARCANTONIO(e) (iD Elcio MARCANTONIO JUNIOR(f) (D)

(a)FAESA Centro Universitário, Dental School, Department of Clinical Dentistry. Vitória, ES, Brazil.

(b) UniversidadeFederal de Uberlândia UFU, School of Dentistry, Department of Periodontology and Oral Implantology, Uberlândia, MG, Brazil.

(c) Universidade Guarulhos - UnG, Department of Periodontology and Oral Implantology, Dental Research Division, Guarulhos, SP, Brazil.

(d) Faculdade llapeo, School of Dentistry, Department of Dentistry, Curitiba, PR, Brazil.

(e) Centro Universitário de Araraquara Uniara, School of Dentistry, Department of Dentistry, Araraquara, SP, Brazil.

(f) Universidade Estadual Paulista - Unesp, School of Dentistry, Department of Diagnosis and Surgery, , Araraquara, SP, Brazil

Declaration of Interests: The authors certify that they have no commercial or associative interest that represents a conflict of interest in connection with the manuscript.

Corresponding Author:

Elcio Marcantonio Jr

E-mail: elciojr@foar.unesp.br

https://doi.org/10.1590/1807-3107bor-2019.vol33.0073

Submitted: June 10,2019

Accepted for publication: June 13, 2019

Last revision: June 19.2019
Abstract: Soft tissue defects around dental implants, such as papilla or volume loss, peri-implant recession and alterations of the ridge color and/or texture, lead to esthetic and functional complaints. Treatments of these defects in implants are more demanding than in teeth because peri-implant tissue exhibits different anatomical and histological characteristics. This narrative review discusses the proposed treatments for soft tissue defects around implants in the current literature. Several clinical and pre-clinical studies addressed methods to augment the quantity of the peri-implant keratinized mucosa. Autogenous grafts performed better than soft tissue substitutes in the treatment of soft tissue defects, but there is no clinical consensus on the more appropriate donor area for connective tissue grafts. Treatment for facial volume loss, alterations on the mucosa color or texture and shallow peri-implant recessions are more predictable than deep recessions and sites that present loss of papilla. Correction of peri-implant soft tissue defects may be challenging, especially in areas that exhibit larger defects and interproximal loss. Therefore, the regeneration of soft and hard tissues during implant treatment is important to prevent the occurrence of these alterations.

Keywords: Dental Implants; Esthetics; Therapy, Soft Tissue; Transplants.

\section{Introduction}

Dental implants have been used for decades to treat tooth loss in several clinical situations. ${ }^{1}$ With a proper treatment plan, placement of the implant in the correct tridimensional position and reconstruction of the lost tissues produce satisfactory results that are maintained over time. ${ }^{2}$ However, some esthetic and/or functional alterations may occur in the soft tissues that jeopardizes the success rate of these implants. ${ }^{2,3}$

The alveolar ridge undergoes clinical and biological modifications after tooth extraction that result in soft and hard tissue loss. If no bone graft is performed in an intact socket, a loss of approximately half of the socket volume may be expected, with major loss in the facial bone wall. ${ }^{4,5}$ Socket grafting may reduce the volume loss to $5-15 \%$ but the bone graft itself cannot maintain the alveolar ridge volume in its plenitude. ${ }^{5,6}$ Consequently, soft tissue grafts may be used to achieve better clinical results, compensate the alveolar ridge loss and provide a more stable peri-implant mucosa around implants. ${ }^{7}$ 
Some papilla loss around dental implants is expected regardless of the type of implant placement, especially when several surgical procedures are performed to rehabilitate a patient. ${ }^{8}$ This loss may be reduced by performing a flapless immediate implant and provisional placement, but approximately $0.5 \mathrm{~mm}$ of the papillae migrates apically. ${ }^{9}$ Reducing these values facilitates the rehabilitation of patients because only the tip of the papilla is compromised, and the final restoration contour provides an appropriate outcome. The treatment of these alterations for greater losses becomes more complicated, and one major consideration for the rehabilitation of a patient with implants is the prevention of papilla loss because surgical reconstruction of this area remains unpredictable., ${ }^{9,10}$

If there is bone loss at the facial aspect of the implant and the patient presents a thin biotype, the soft tissue margin can migrate apically and generate esthetic or functional complaints. ${ }^{11}$ Soft tissue recessions in implants leads to a longer prosthetic crown with incorrect tooth proportion or abutment, and the implant may also be exposed, which makes plaque control even harder, especially if there is lack of keratinized mucosa. ${ }^{12,13}$ Therefore, patients may request some type of treatment to prevent further tissue loss or to regain previously lost tissue.

Treatment of soft tissue defects around implants is challenging, especially in the esthetic region (Figure 1). To quantify soft tissue esthetic parameters, the Pink Esthetic Score ${ }^{14}$ was developed to evaluate mesial and distal papilla, soft tissue margin and contour

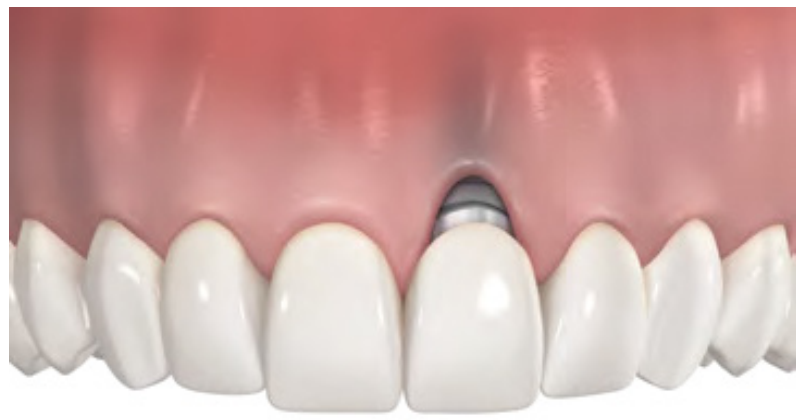

Figure 1. Clinical alterations in an implant placed in the anterior region. and alveolar process volume, color and texture. Each variable receives a grade from 0 to 2 , and the patient soft tissue esthetic receives an overall value from 0 to 14. Belser et al. ${ }^{15}$ modified the original score, and the revised evaluation varies from 0 to 10 . The variables of the alveolar process (volume, color and texture) were condensed into one analysis, which the authors justified because these variables were not considered as equally important as the other variables.

Similarly, the correction of peri-implant recession or papilla loss is more technically demanding than increasing the soft tissue volume or treating color and texture alterations. This narrative review discusses these types of soft tissue defects around implants and the possible treatments proposed in the scientific literature.

\section{Facial volume loss, color or texture alterations}

Loss of facial volume generally occurs after tooth extraction, especially if there is a bone defect in the socket. A great percentage of resorption occurs in the first 3 months, but resorption may continue up to years after extraction in sockets that originally contained a facial bone wall. ${ }^{16}$ If the implant is placed with no further soft or hard tissue regeneration, then the mucosa may become thin and present a grayish color in the facial aspect. ${ }^{17}$ Additionally, the soft tissue texture may present scars depending on where the incisions are placed and how the flap is managed; soft and hard tissue grafts may also alter the tissue texture if exposed. ${ }^{18}$

A ridge concavity in the area that received an implant may become a concern for patients who present high esthetic demands. Volume loss is part of a physiological phenomenon that occurs after tooth extraction. Several researchers demonstrated that the facial wall was partly resorbed due to its thickness, in contrast to a thicker lingual or palatal wall that generally exhibits less resorption. ${ }^{5,6,16}$ Bone grafts reduce the volume loss, and deproteinized bovine bone mineral (DBBM), which are small-sized particles of autogenous bone and synthetic materials, such as beta tricalcium phosphate, exhibit more stability but show limited results as materials to prevent ridge resorption..$^{5,6,16,19}$ A human autopsy 
study of one patient who received implants in healed ridges and presented a facial dehiscence that was grafted with distinct bone grafts showed very different clinical and histological results. One side was grafted with deproteinized bovine bone mineral and a collagen membrane, and the other side received autogenous bone chips in contact with the implant followed by a biphasic calcium phosphate graft and a collagen membrane. The implant grafted with the autogenous and synthetic bone grafts exhibited recurrence of bone dehiscence and mucosal recession at the facial aspect. ${ }^{20}$

The loss of facial volume may be associated with a thin or nonexisting facial bone wall. Consequently, the soft tissue also becomes thin in such areas, which may predispose the patient to develop mucosal recession or color alterations. Tissue thickness is classified as thin when it is less than $2 \mathrm{~mm}$ at the facial aspect, and as thick if presents a value greater than $2 \mathrm{~mm}$. Depending on the thickness of the mucosa, the facial color may be altered by showing the implant or abutment due to transparency. ${ }^{21} \mathrm{An}$ in vitro study compared the color alterations of metal or zirconia abutment in different mucosa thickness. No color alterations were perceived when the mucosa exhibited a thickness of $3 \mathrm{~mm}$. Titanium abutments showed a grayish area at the facial aspect in the presence of a $2 \mathrm{~mm}$ thick mucosa, while zirconia abutments did not and provided a better color aspect. If the tissue exhibited a thickness of $1.5 \mathrm{~mm}$, all abutments showed discoloration of the mucosa. ${ }^{22}$ To treat color alterations that occur due to reduced tissue thickness and transparency of the mucosa, a soft tissue graft may be indicated to augment the facial volume and provide stable results in the long term. ${ }^{23}$ Different types of soft tissue grafts are used for different purposes around teeth or implants. To increase soft tissue volume, autogenous connective tissue grafts (CTG) provided better results than homogenous acellular dermal matrices or heterogenous collagen matrices. ${ }^{9,11,23}$

Depending of the extent of volume loss, the defect may be treated with a CTG and different types of flaps. If the implant is submerged and the defect at the cervical area is smaller than $2 \mathrm{~mm}$, a lingual incision to facially position the flap solves the volume issue. If the defect is greater than $2 \mathrm{~mm}$, a CTG must be associated with this type of flap. In situations where the implant is already exposed and exhibits a healing abutment, provisional or ceramic crown, the defect may be treated with a CTG and pouch flap if the defect is smaller than $2 \mathrm{~mm}$. For larger defects (> $2 \mathrm{~mm}$ ), an envelope flap may be performed and associated with a CTG to provide better volume at the facial aspect. A systematic review demonstrated that the use of autogenous soft tissue grafts to increase mucosal thickness resulted in less marginal bone loss over time. ${ }^{7}$

Care must be taken whenever performing incisions in esthetic regions to avoid the formation of scars. Wessels et al..$^{18}$ proposed a scar index that evaluates the scar width, height/contour and color and classifies the visibility of the suture marks and the overall appearance. A randomized clinical trial compared the soft tissue response after intrasulcular and trapezoidal incisions. Scars were present in the trapezoidal group and clearly visible in greater than $85 \%$ of the mesial and distal vertical incisions 1 month after surgery. After 12 months, the scars were less pronounced but could still be identified in more than half of the performed trapezoidal incisions. ${ }^{24}$

To improve the soft tissue texture and reduce scars in the facial aspect of an implant, a mucosal peeling may be performed by using a surgical blade, conventional or ceramic burs or a high frequency laser. ${ }^{25}$ It is important to evaluate tissue thickness prior to peeling. If the tissue is thin, then its removal may lead to soft tissue alterations, such as recession or loss of papilla, and a CTG may be indicated to increase tissue thickness prior to scar removal in this situation.

\section{Peri-implant recession}

In the past, peri-implant recession (PIR) was a common condition in implant dentistry because the implants were installed in the existing bone, and the primary endpoint of the therapy was to provide masticatory function. With the evolution of implant systems, prosthetic and surgical techniques, it became possible to restore a single missing tooth, but most implants exhibited longer clinical crowns. ${ }^{26}$ The current understanding of the importance of 
tissue regeneration and implant selection and positioning to provide better esthetic outcomes allows clinicians to restore implants even in highly demanding situations. ${ }^{9}$

Multiple factors influence in the occurrence of PIR, including implants that were placed facially or apically, areas that exhibit bone dehiscence, thin periodontal biotype, an improper quantity of keratinized tissue and areas submitted to trauma. ${ }^{27,28}$ Similar to gingival recession, peri-implant margin apical migration tends to increase over time, and regular maintenance is important to identify the factors causing the tissue loss. In esthetically demanding situations or progressive recession, treatment must be performed to stabilize or recover the lost mucosa. ${ }^{12,13}$

The presence of keratinized mucosa is widely discussed to define its role in the prevention of inflammation, PIR and diseases. Some long-term retrospective studies demonstrated that reduced keratinized mucosa width and shallow vestibules were associated with more recession and bone loss, ${ }^{29}$ and performing an apically positioned flap and autogenous free gingival graft led to better clinical outcomes and prevented peri-implant recession and inflammation. ${ }^{30}$ Oral hygiene becomes easier to perform, especially in posterior regions after increasing the width of keratinized mucosa and the vestibule, which also prevents or limits the occurrence of peri-implant diseases. ${ }^{27,29}$

Implants that exhibited a large diameter or platform used to be placed in sockets or ridges to restore anterior teeth. ${ }^{31,32,33}$ Peri-implant recessions occurred in these situations, especially in patients who exhibited a thin biotype or facial wall, and who did not receive guided bone regeneration or soft tissue grafting to increase tissue thickness. Kan et al. ${ }^{34}$ performed immediate implant placement and provisionalization in maxillary anterior sockets without performing any type of grafting. A mean peri-implant recession of $0.55( \pm 0.53) \mathrm{mm}$ was reported, but most of the implants $(74.28 \%)$ were placed in maxillary central incisor sockets, which are more predisposed to ridge dimensional changes than maxillary lateral incisors. The patients from this study were reevaluated after a mean follow up of 4 years (range 2 to 8.2 years), and a significant difference in the extent of peri-implant recession in biotypes classified as thin (recession $=1.50 \pm 0.88$ ) compared to thick (recession $=0.56 \pm 0.46$ ) was reported. ${ }^{35}$

Bone morphology was associated with periimplant thickness and recession in a clinical study. ${ }^{36}$ Thicker facial bone walls were correlated to thick biotypes, and bone walls that were thin or exhibited a dehiscence defect were associated with longer clinical crowns or recession, respectively. ${ }^{36} \mathrm{~A}$ minimum bone thickness of $1 \mathrm{~mm}$ must be achieved in the facial aspect of the implant to provide more stability and nutrition to the mucosa. Several studies have shown that the selection of the implant proper diameter and placement in a lingual position creates or maintains proper thickness of the facial tissue when bone and soft tissue grafting are performed. $9,31,35$

Treatments of PIR around implants are more complex than teeth. The peri-implant tissue has a lower blood supply, and its fibers differs from the gingiva. ${ }^{37}$ To increase treatment predictability, other characteristics must be evaluated prior to soft tissue grafting of implants with PIR. Implant size, quantity and position, prosthetic abutment and contour, the extent of the bone defects at the facial and interproximal levels are important aspects that play major roles in implant coverage. ${ }^{33}$ Depending on the clinical situation, implant removal, followed by ridge reconstruction and placement of a new implant in the proper tridimensional position, provide a more predictable outcome and better prognosis than soft tissue grafting for implant coverage (Table).

The implant position and prosthetic contour (abutment and provisional/crown) is important to achieve predictable results. The implant inclination and crown emergence must not cross a line that connects the adjacent tooth at the cervical region, meaning that the implant/prosthesis should not occupy the space where the mucosa should be. In these situations, the abutment must be horizontally reduced and exhibit a concave contour to provide more space for the soft tissues; some authors have even proposed facial implantoplasty to increase PIR coverage. ${ }^{38}$ The vertical position of the finishing line of the abutment must be moved coronally to near or at the level of the soft tissue margin of the contralateral tooth/implant. 
Table. Factors that influence prognosis of implant coverage with soft tissue grafts.

\begin{tabular}{lccc}
\hline Factor / Prognosis & Good & Moderate & Bad \\
\hline Implant 3D position & Proper & Fair & Malpositioned \\
Prosthetic/abutment contour & Concave & Flat & Convex \\
Implant diameter & Narrow & Regular & Large \\
Tissue thickness & Thick & Thin & Thin with fenestration \\
Peri-implant recession & Shallow & Moderate & Deep \\
Distance implant platform to bone crest & $<3 \mathrm{~mm}$ & Small defect & Large defect \\
Interproximal tissue loss & None & Tooth and implant & Implants \\
Implant adjacent to & Teeth & At bony envelope limit & Outside \\
Position of the implant within bony envelope & Inside & . & inm \\
\hline
\end{tabular}
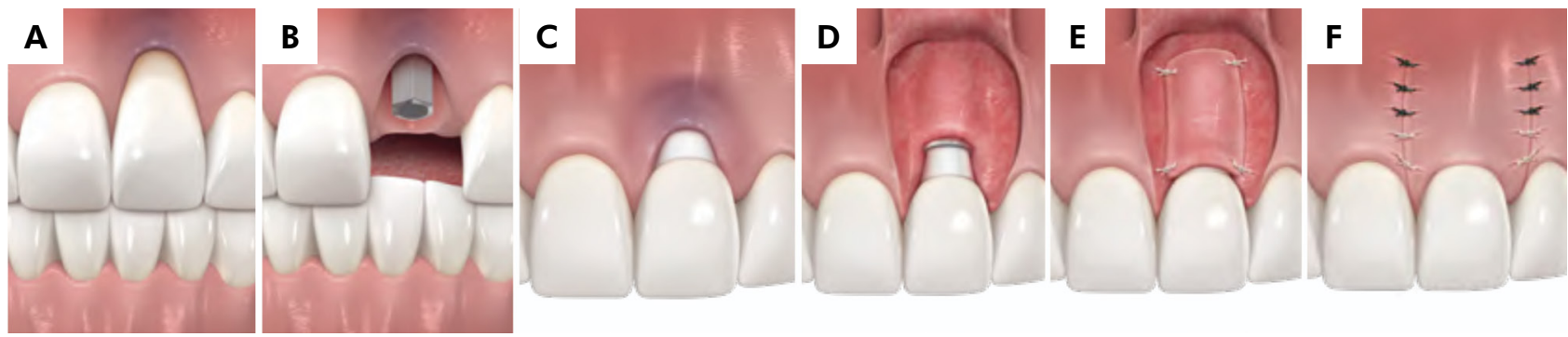

Figure 2. An implant that had a thin biotype and peri-implant recession (a) was treated by using a combination of prosthetic and surgical procedures. The implant crown and metal abutment (b) were removed, and an impression of the implant was performed to create a new zirconia abutment with a concave contour, in which the finishing line was placed at the level of the soft tissue margin of the contralateral tooth (c). Two vertical incisions were performed to create a full/split thickness flap (d). A thick connective tissue was sutured at the level of the abutment finishing line (e), and the flap was positioned coronally (f).

An implant with an adequate diameter that is placed in a favorable tridimensional position within the bony envelope with limited or without interproximal tissue loss is a good candidate to receive soft tissue grafting for the treatment of PIR. Although there are few prospective studies that address this type of defect, partial to full coverage may be expected depending on the extent of the clinical alteration and overall prognosis. ${ }^{2,12,38,39}$ Shibli et al..$^{40}$ proposed one of the first published methods to treat PIR in 2004 and reported that recession was successfully treated by using a combination of prosthetic and surgical procedures. The abutment diameter and provisional were initially reduced in its facial aspect followed by a coronally advanced flap (CAF) that was associated with a thick CTG graft (Figure 2).

Because there are many variables in the diagnosis, indication for treatment and prognosis, few clinical studies report data on coverage of peri-implant recessions. Burkhardt et al. ${ }^{12}$ evaluated 10 patients who underwent soft tissue augmentation to treat a single PIR with a mean value of $3 \mathrm{~mm}$ (SD $0.8 \mathrm{~mm}$ ). The connective tissue graft removed from the palate exhibited a thickness of 1.5-2 $\mathrm{mm}$, and a flap with two vertical incisions was coronally advanced $2 \mathrm{~mm}$ further to a landmark measured in the contralateral tooth; there was no report of implant abutment or prosthesis modification. Six months after the procedure, there was a mean coverage of $66 \%$ (SD $18 \%$ ) of the peri-implant recessions, and a positive correlation between flap thickness and recession coverage was reported.

A prospective study was performed to treat PIR and presented clinical results after one ${ }^{38}$ and five years of follow-up. ${ }^{13}$ After patient selection, the prosthesis abutment was reduced at the facial 
aspect one month prior to the surgical procedure. The flap was also performed with two vertical incisions, and the exposed implant threads were removed with diamond burs and polished with rubber cups. A two-millimeter-thick CTG derived from the de-epithelization of a free gingival graft was placed at the implant-abutment surface, and the flap was coronally advanced. After one year of follow-up, the authors reported a mean coverage of $96.3 \%$, and $75 \%$ of the sites exhibited full coverage. The results after the five-year follow-up demonstrated the stability of the procedures performed in the initial study. ${ }^{13}$

The combination of a coronally advanced envelope flap with a CTG removed from the maxillary tuberosity was used to treat shallow peri-implant recessions. ${ }^{2}$ A mean coverage of $89.6 \%$ (SD 13.1\%) was achieved one year after the procedure, and complete coverage was possible in $56.3 \%$ of the patients. After five years of follow-up, the results were stable and showed $86 \%$ of soft tissue coverage (SD 19\%), which demonstrated the effectiveness of the soft tissue augmentation procedure. ${ }^{41}$

Few studies report the use of soft tissue substitutes to treat peri-implant recessions. Anderson et al. ${ }^{39}$ performed a randomized controlled clinical pilot trial to evaluate an acellular dermal matrix compared to the CTG. All patients received a CAF and one of the grafts, and the implant crowns were not reduced or removed. After six months of follow up, improvement of the recessions was low and represented a coverage of $40 \%$ for the CTG group and $28 \%$ for the allograft. The patients did not report an improvement of esthetic ratings, and the soft tissue substitute exhibited more eventful wound healing. An animal study that evaluated the treatment of peri-implant recessions with either CTG or a collagen matrix reported similar results in coverage. ${ }^{42}$ The major issue about using first generation collagen matrices to treat soft tissues defects is the limited increase in tissue thickness. ${ }^{9}$ New volume-stable collagen matrices were produced and are under investigation for dimensional stability in the long term.

The available data in the scientific literature demonstrate that a CAF in combination with an autogenous soft tissue graft provide a decent rate of success in the treatment of soft tissue deficiencies around implants, which demonstrates the possibility to increase tissue height and volume in the long term. ${ }^{13.41}$ The decision of the design of the flap will depend on the extent of the peri-implant recession, vestibular depth, quantity of attached mucosa and the amount of interproximal tissue. For shallow recessions (Figures 3-5), generally an envelope ${ }^{43}$ or pouch procedure is indicated. ${ }^{44}$ If there is a moderate or deep recession, two vertical incisions, as initially proposed by Langer and Langer, ${ }^{45}$ will provide a more tension-free flap that can be freely positioned and stabilized coronally.

Treatment of PIR is definitely a more challenging procedure than gingival recessions. One major factor that influences the outcome of the coverage of roots or implant surfaces is the amount of interproximal tissues. There are not enough studies to quantify the percentage of implant coverage based on the aspect of the papillae, but cases who exhibit none or limited tissue loss may
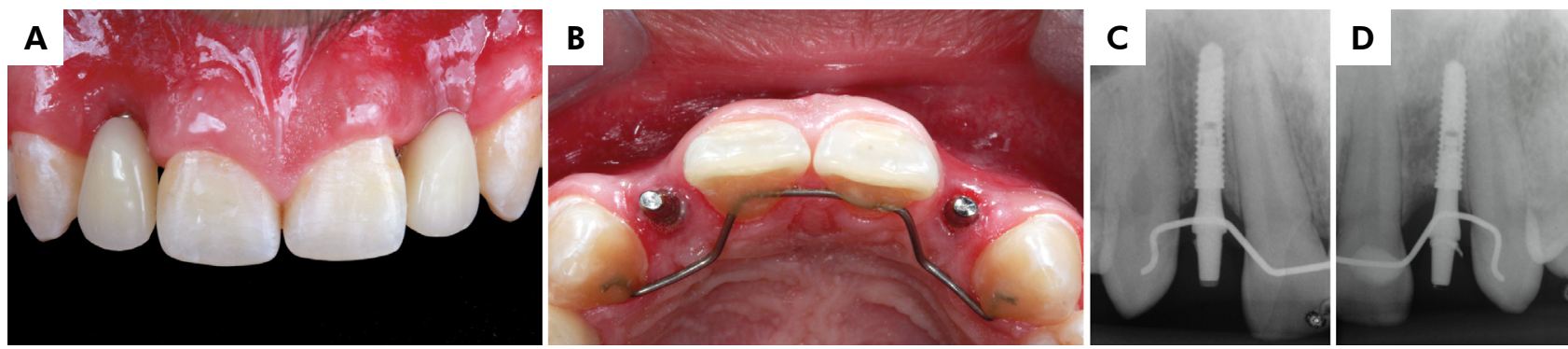

Figure 3. Patient presented loss of facial volume and papillae, color alteration and peri-implant recession (a,b) at both implants sites (\#12 and \#22). Even though the implants presented stable peri-implant bone at the interproximal aspect (c,d), there were esthetic and functional complaints. 

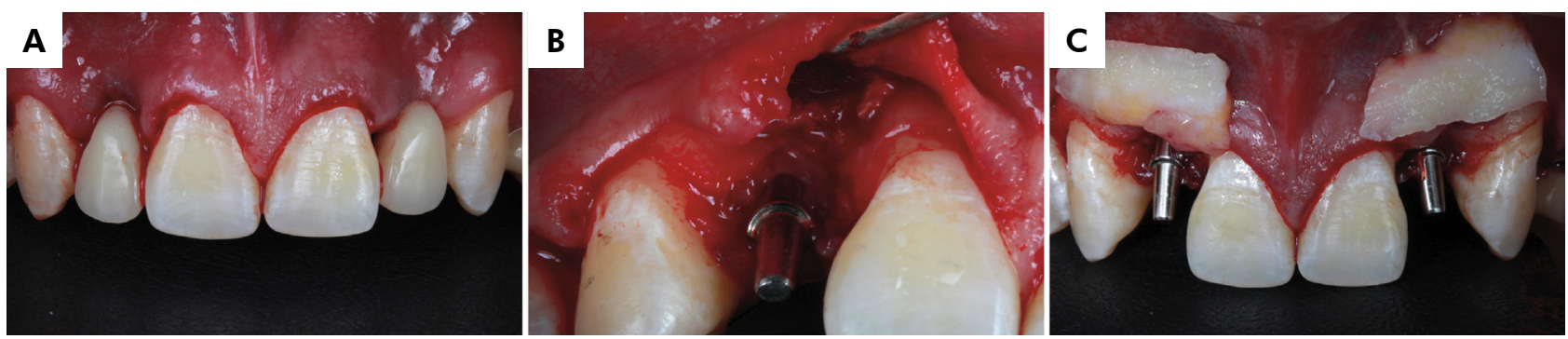

Figure 4. To provide a better esthetic outcome, surgical crown lengthening was performed on both maxillary central incisors (a). There was no facial bone loss at the implants' facial aspect (b), but there was a large ridge deficiency in volume. Two thick CTG were harvested from the palate to compensate ridge volume loss and increase the tissue thickness (c).
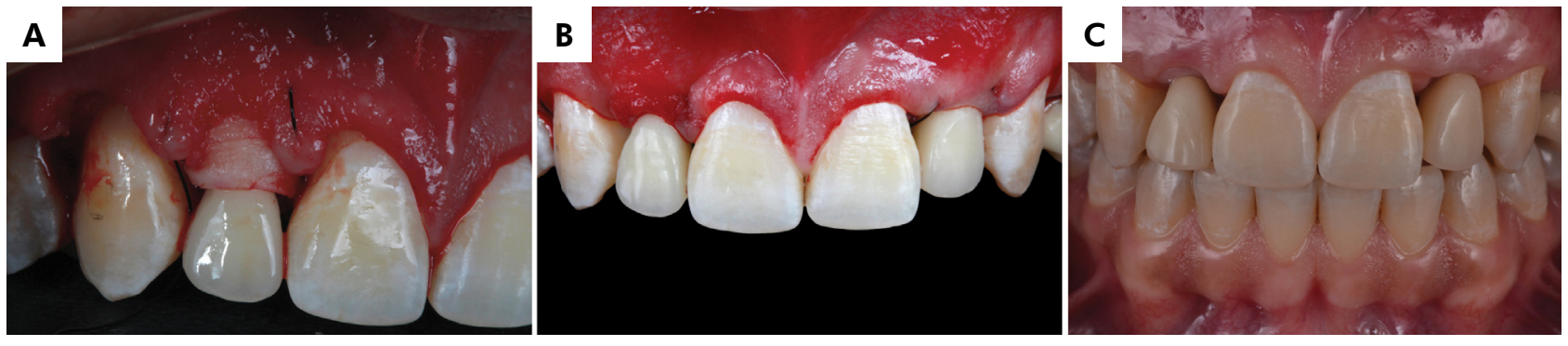

Figure 5. The CTGs were sutured at the implants' facial aspect (a), and the flap was coronally positioned (b). Three months after healing, the ridge volume and soft tissue margins were improved, but the papillae were still missing (c).
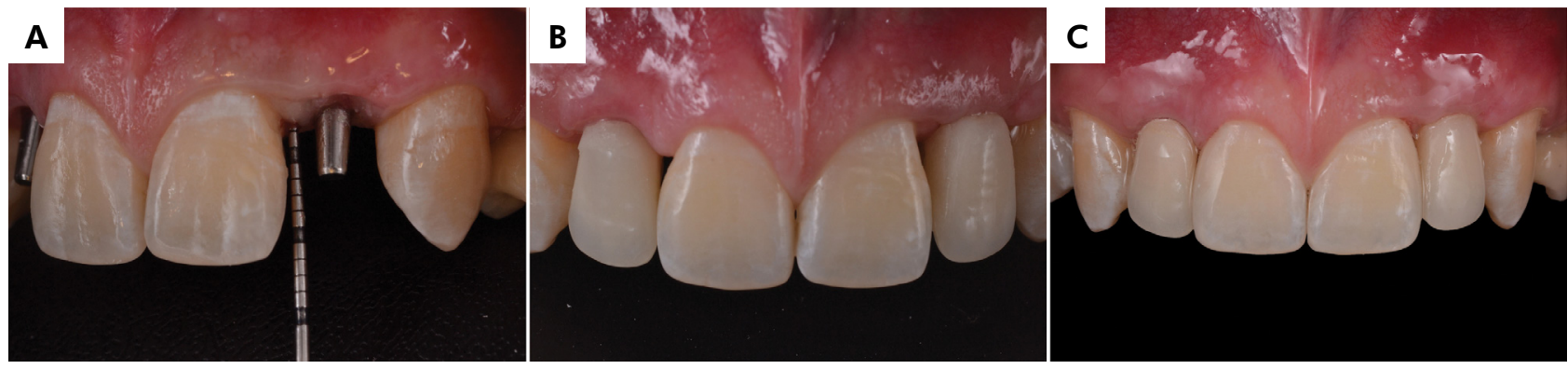

Figure 6. The distance between the bone crest and the tip of the papillae was $3 \mathrm{~mm}$ in height (a). The anatomy of the implants provisional restorations (b) and the distal aspect of the maxillary central incisors (c) were modified, and the contact point was shifted apically.

experience better outcomes than sites with partial or complete loss of papilla.

\section{Papilla loss}

Interproximal tissue loss may lead to esthetic and functional complaints, and surgical recovery of lost papillae around teeth or implants is not an easy or predictable task to undertake for preventing this loss; however, preventing papilla loss must be one of the implant treatment goals. The papillae can be maintained in areas that received an implant if the adjacent tooth bone crest is intact and there is no periodontal attachment loss, but there should be a proper contour and contact point (Figure 6). ${ }^{32,46}$ In situations where the adjacent teeth exhibit interproximal bone defects or the periodontal support is compromised, the papillae may be partially or fully lost. A papilla index score was developed ${ }^{47}$ and classified into five types: 0 - no papilla; 1- papilla are less than $50 \%$ of the height of the interproximal space; 2- papilla are greater than $50 \%$ but less than $100 \%$ of the height of the 


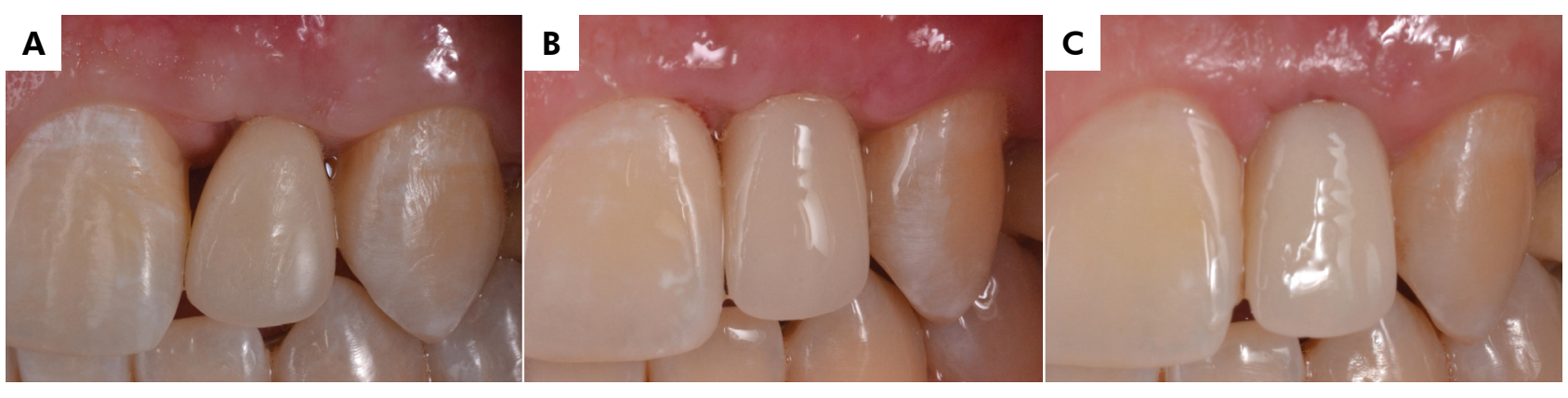

Figure 7. Clinical aspect prior to new restorations (a), immediately after (b) and one year later (c) showing the vertical growth of the papillae after surgical and restorative procedures.

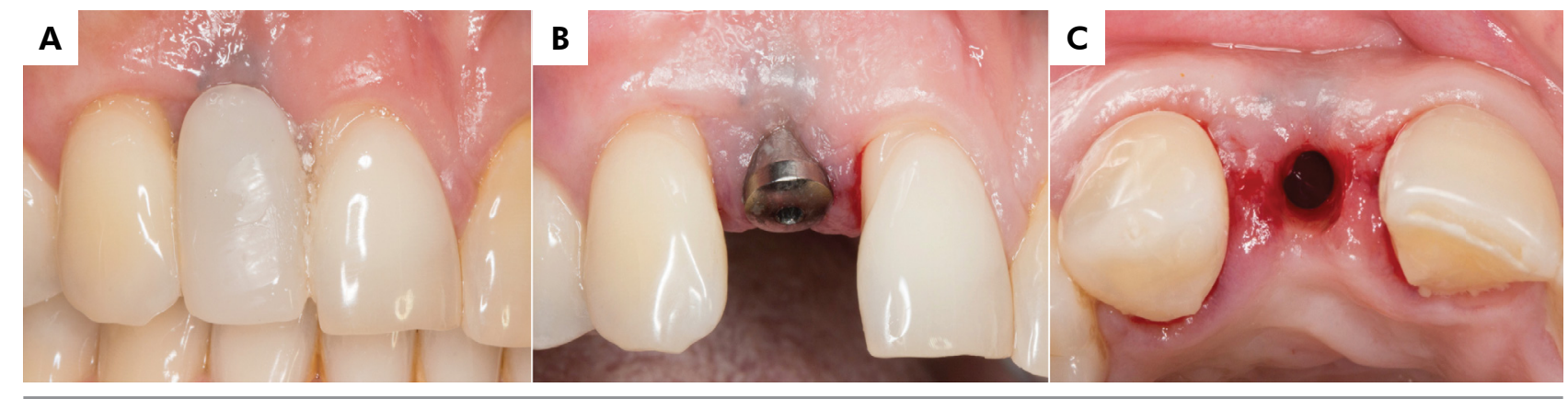

Figure 8. Patient complained due to loss of papillae at the implant site (a). The implant with a Morse taper connection was already placed in the proper mesio-distal positioning (b), so the healing abutment was removed to perform a CTG and improve the tissue contour and height (c).

interproximal space; 3- full papilla; and 4- papilla exhibits overgrowth.

Tarnow et al. ${ }^{48}$ associated the distance from the contact point to the bone crest with the presence of papilla between teeth in humans. When this distance was $\leq 5 \mathrm{~mm}$, the papilla was present in all sites. If the distance was equal to $6 \mathrm{~mm}$ or $7 \mathrm{~mm}$, papilla were present only $56 \%$ and $27 \%$ of the time, respectively. These measurements were performed in areas between teeth, but other studies evaluated the vertical height of the papilla in different clinical situations, including sites with implants and pontics. ${ }^{49,50}$ The distance between the bone crest and the tip of the papilla generally measured $4.5 \mathrm{~mm}^{49}$ in sites where an implant was placed adjacent to a tooth (Figure 7). The papilla between implants are the more critical situation and exhibited an average $3.4 \mathrm{~mm}$ of soft tissue height. ${ }^{50}$ Therefore, adjacent implants in esthetic areas should be avoided if the patient has a high smile line or esthetic demands. ${ }^{32}$ Correct planning and distribution of implants in the esthetic region may increase treatment predictability because areas that are adjacent to or between pontics may exhibit 5.5 or $6 \mathrm{~mm}$ of tissue height, respectively. ${ }^{49}$

There is limited evidence regarding surgeries to treat papilla loss, and most publications address case reports or series for the treatment of these alterations around teeth or implants. Surgical reconstruction of papillae is challenging due to the limited blood supply, which is important for proper tissue healing. Feuillet et al. ${ }^{51}$ published promising outcomes in a case series of the treatment of papilla loss between teeth using tunneling flaps associated with CTG from the tuberosity. These authors reported that an experienced surgeon with training in microsurgical techniques, which must be performed with specific instruments, should perform the procedure.

Evaluations of implants papillae were performed after second stage surgery and demonstrated an improvement in the papilla index score ${ }^{47}$ after soft tissue manipulation and prosthetic rehabilitation. ${ }^{52}$ In ridges that exhibited soft tissue deficiency, it was 
possible to stabilize a long and thick CTG over the facial and occlusal aspect (Figure 8) to increase tissue volume and height..$^{53}$ The graft should be submerged, and interproximal sutures may be used to coronally advance the papillae. Urban et al. ${ }^{46}$ suggested a prosthetic and surgical approach to recreate the papillae (Figures 9 and 10). Even after extensive bone regeneration, the interproximal bone remained compromised, an implant was placed, and a thick CTG from the palate was placed at the occlusal portion of the ridge to compensate for vertical tissue loss. Six months later, the implant received a temporary crown, and the tissue was conditioned to receive a zirconia abutment with a convex interproximal contour to support the recreated tissues.

Papilla loss was also treated by using nonsurgical methods, such as repeated curettage, injections with micronized acellular dermal grafts or hyaluronic acid, and restorative or orthodontic procedures. ${ }^{54,55,56,57,58,59}$ Several factors influence the treatment of papilla loss with filler materials, such as hyaluronic acid, and the clinical results obtained from human studies presented more promising results in areas between teeth ${ }^{59,60}$ than implants. ${ }^{61}$ Restorative or orthodontic procedures may be performed to condition the soft tissue and create interproximal papilla around implants.

Areas that still present deficiency in the papilla can have the proximal contour of the implant provisional crown or adjacent tooth altered, but the contact point of the restoration must be placed more apically. In sites where the implant is adjacent to a tooth, a distance of at least $4.5 \mathrm{~mm}$ must be established between the contact point and the bone crest to reduce the black triangle and stimulate papilla growth; whenever there are adjacent implants, this distance must be reduced to $3.5 \mathrm{~mm} .^{50}$ Time is an important factor to allow tissue growth, and there is a clinical trend to increase papilla height with long-term follow-up if a patient does not exhibit periodontal attachment loss in the adjacent tooth. ${ }^{35}$

Tooth slow extrusion is the more predictable procedure for creating both interproximal bone and soft tissue in an implant-tooth site. The orthodontic

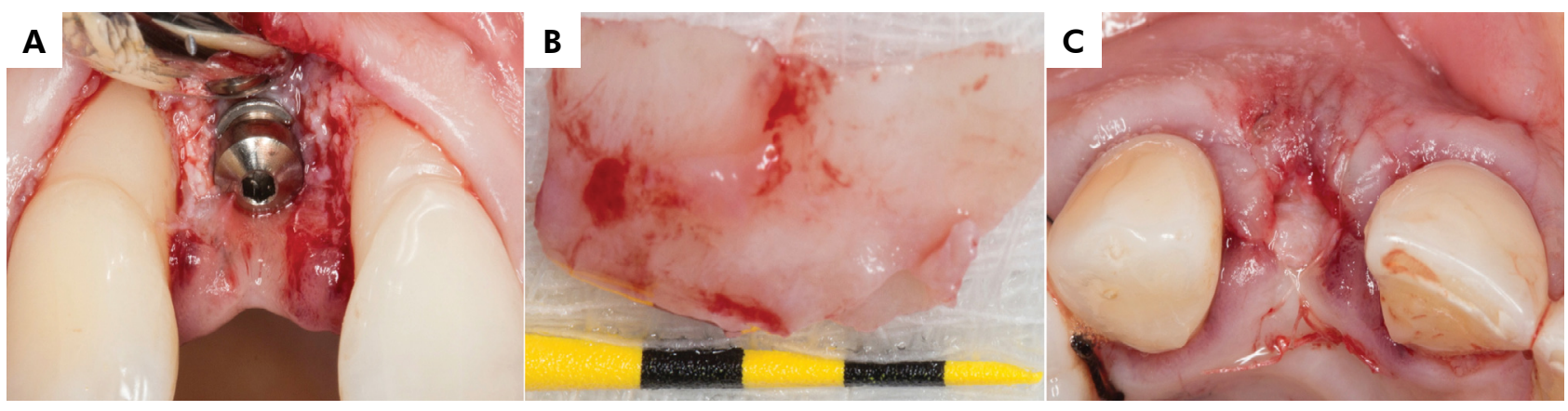

Figure 9. There was a small bone defect at the facial and interproximal aspects (a). A thick CTG (b) was harvested from the palate and placed at the implant site facial and occlusal aspects (c).

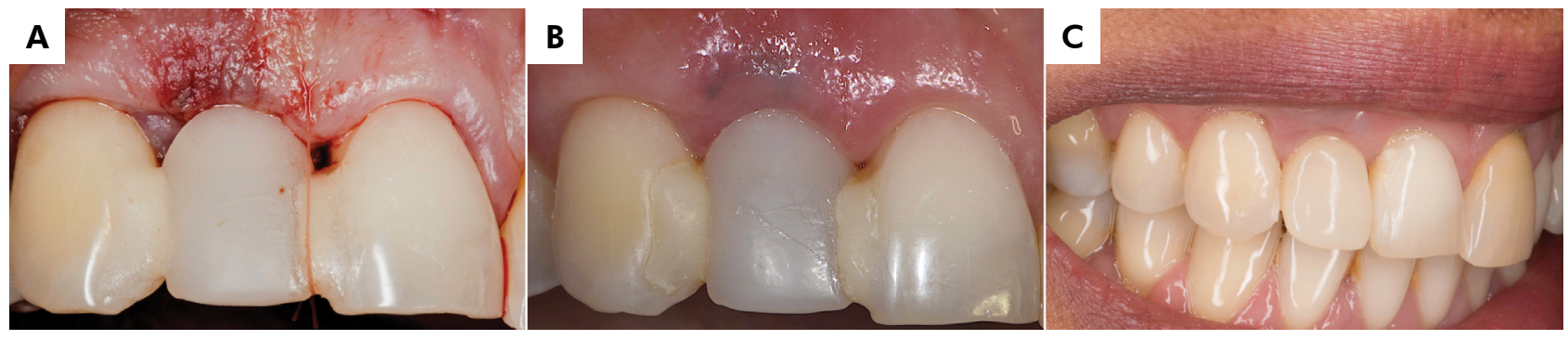

Figure 10. The papillae and flap were coronally advanced with sutures (a). Clinical aspect one month (b) after the surgery and one year after performing an implant restoration. 
extrusion rate should not be greater than 1-2 mm per month, ${ }^{62}$ and the tooth occlusal contacts must be progressively adjusted to avoid trauma; after finishing the movement, the tooth must be maintained in position for 3 to 6 months to facilitate bone formation at the interproximal and apical aspect of the tooth. ${ }^{63}$ After slow extrusion, the facial soft tissue also moves coronally and may need a flapless crown-lengthening procedure to improve the esthetic outcome. ${ }^{64}$

\section{Discussion}

There is limited scientific evidence regarding the treatment of esthetic soft tissue defects in implants; therefore, prevention must be considered to avoid complications. It is important to identify patients and clinical situations that are more susceptible to the future occurrence of peri-implant alterations. A thin biotype, absence of keratinized tissue, extensive bone defects, high smile line or esthetic demand, infection, smoking, and patient medical status are conditions that can jeopardize implant treatment in the esthetic area. ${ }^{33}$

Even though the alveolar ridge undergoes continuous resorption after tooth extraction, most of the volumetric alterations occur in the first year, especially in the initial months. ${ }^{4}$ Socket preservation procedures have been advocated and are often used to preserve the dimensions of the alveolar ridge and allow the ideal placement of an implant in a less demanding situation. ${ }^{5}$ Long-term stability of the grafted site is important to avoid the future occurrence of a concavity defect in the esthetic region. Whenever socket preservation or lateral augmentation is performed, selection of the appropriate type of bone graft is important to avoid alterations. Onlay autogenous bone ${ }^{65,66}$ or deproteinized bovine bone mineral used alone $e^{2,67-70}$ or in association with bone chips $^{71,72}$ have been documented and presented stable results in the long term. Complications may occur when performing bone regeneration, and sites that received autogenous bone blocks exhibited greater loss of the papillae due to multiple surgical interventions and increased surgery time. ${ }^{73}$ Additionally, if the bone graft becomes exposed, the amount of augmentation is reduced, and soft tissue scars becomes more evident.
Proper soft tissue contour and thickness are important factors to establish a good outcome in implants installed in esthetic regions. Reduced tissue thickness is associated with color alterations when titanium abutments are placed and is more prone to recession in long-term follow up. ${ }^{22,35}$ Abutments made of fluorescent zirconia or that exhibited a gold or pink color provided better clinical results in areas with a thin biotype ${ }^{74}$ but there was always a threshold volume that presents a color alteration. ${ }^{75}$ In these situations or in patients who present a high risk of recession soft tissue, augmentation is generally indicated. ${ }^{9}$

The absence of keratinized mucosa or even a thin peri-implant biotype was associated with periimplantitis, ${ }^{76}$ which is a plaque-associated disease around dental implant tissues that generally exhibits greater recession after treatment. To prevent further recession, soft tissue augmentation may also be performed in conjunction with peri-implantitis treatment. ${ }^{77}$ Autogenous soft tissue grafts performed better than soft tissue substitutes to increase tissue thickness or treat PIR. ${ }^{9,23}$ Previously tested collagen matrices demonstrated limited potential to increase tissue thickness, and new volume-stable matrices ${ }^{78,79,80}$ have produced promising results for soft tissue augmentation; however, more studies are needed to improve tissue stability in the long term. Use of an acellular dermal matrix was associated with impaired wound healing and more exposure compared to autogenous soft tissue grafts, but its volume stability in the long term must be established. ${ }^{39}$

Several types of autogenous soft tissue grafts are used to treat peri-implant recession in properly placed implants. Studies report outcomes from CTG removed from the palate using the single incision technique and free gingival grafts that were de-epithelized or removed from the tuberosity. ${ }^{2,12,38}$ Establishing the type of CTG must consider the clinical aspects of each patient, and one factor is of major importance: the graft must exhibit a thickness of $2 \mathrm{~mm}$ or greater. Rojo et al. ${ }^{1}$ compared the volume alterations of grafts removed from the palate or the tuberosity and reported no difference after 3 months of follow-up. Although the graft from the tuberosity exhibited several advantages, such as 
less morbidity and postoperative pain, more dense collagen fibers with less fat and glandular tissue, ${ }^{82}$ care must be taken because the tissue may develop an overgrowth with long-term follow up, and the patient must be aware of this possibility prior to soft tissue augmentation.

The decision between performing soft tissue grafts in an implant with soft tissue recession or removing it must consider the extent of the defects, patients' expectations and implant positioning. The experience of the surgeon plays an important role in the occurrence or prevention of peri-implant recession. A clinical study of immediate implants placed in sockets compared the outcomes of senior surgeons and residents in implant dentistry. This study showed that the apical migration of the soft tissue margin was more frequent in patients who were treated by residents. ${ }^{83}$ Surgical expertise to place the implant in the proper tridimensional position in sockets or ridges is an important factor to prevent soft tissue defects, and creating a multidisciplinary treatment plan is crucial to provide better esthetic and functional outcomes. ${ }^{53}$

Surgical reconstruction of the papilla around teeth or implants is the "Achilles heel" of contemporary Periodontics and Implant Dentistry, and it shows low rates of predictability. Prevention is important to reduce papilla height, and minimally invasive surgical procedures, such as flapless placement of implants in sockets or healed ridges and tissue regeneration, limit the occurrence of this alterations. ${ }^{9,35}$ Restorative or orthodontic procedures compensate for interproximal bone defects or recreate the papilla contour. ${ }^{55,57,62}$ More studies are needed to confirm the possible use of filler materials to increase papilla height and volume in less demanding situations because there are conflicting results of its real potential. ${ }^{59,61}$ Greater defects may be treated by using gingivashade ceramics, but this rehabilitation is not free of esthetic risk because different factors may influence the outcomes, especially in patients with a high smile line and defects restricted to one anterior tooth, which shows the transition between the restoration and the mucosa. ${ }^{84}$

\section{Conclusion}

Correction of peri-implant soft tissue defects is challenging, especially in patients with deep recessions and loss of papillae. Implant sites with loss of volume, color or texture alterations and shallow peri-implant recessions exhibit more predictable outcomes. The regeneration of the soft and hard tissues during the surgical phase of implant treatment plays a major role in preventing the occurrence of soft tissue defects.

\section{Acknowledgments}

The authors thank the publisher Napoleão Quintessence Brazil for providing permission to use the images in this article. All images were recently published in the book "Esthetic Integrated in Periodontics and Implant Dentistry" by the authors Fausto Frizzera, Jamil Awad Shibli and Elcio Marcantonio Jr. ${ }^{85}$

\section{References}

1. Knöfler W, Barth T, Graul R, Krampe D. Retrospective analysis of 10,000 implants from insertion up to 20 years-analysis of implantations using augmentative procedures. Int J Implant Dent. 2016 Dec;2(1):25. https://doi.org/10.1186/s40729-016-0061-3

2. Roccuzzo M, Gaudioso L, Bunino M, Dalmasso P. Long-term stability of soft tissues following alveolar ridge preservation: 10-year results of a prospective study around nonsubmerged implants. Int J Periodontics Restorative Dent. 2014 Nov-Dec;34(6):795-804. https://doi.org/10.11607/prd.2133

3. Avila-Ortiz G, Chambrone L, Vignoletti F. Effect of alveolar ridge preservation interventions following tooth extraction: a systematic review and meta-analysis. J Clin Periodontol. 2019 Jan. https://doi.org/10.1111/jcpe.13057

4. Schropp L, Wenzel A, Kostopoulos L, Karring T. Bone healing and soft tissue contour changes following single-tooth extraction: a clinical and radiographic 12-month prospective study. Int J Periodontics Restorative Dent. 2003 Aug;23(4):313-23.

5. Araújo MG, Lindhe J. Ridge preservation with the use of Bio-Oss collagen: A 6-month study in the dog. Clin Oral Implants Res. 2009 May;20(5):433-40. https://doi.org/10.1111/j.1600-0501.2009.01705.x 
6. Araújo MG, Lindhe J. Socket grafting with the use of autologous bone: an experimental study in the dog. Clin Oral Implants Res. 2011 Jan;22(1):9-13. https://doi.org/10.1111/i.1600-0501.2010.01937.x

7. Thoma DS, Naenni N, Figuero E, Hämmerle CH, Schwarz F, Jung RE, et al. Effects of soft tissue augmentation procedures on peri-implant health or disease: A systematic review and meta-analysis. Clin Oral Implants Res. 2018 Mar;29 Suppl 15:32-49. https://doi.org/10.1111/clr.13114

8. Ryser MR, Block MS, Mercante DE. Correlation of papilla to crestal bone levels around single tooth implants in immediate or delayed crown protocols. J Oral Maxillofac Surg. 2005 Aug;63(8):1184-95. https://doi.org/10.1016/i.joms.2005.04.025

9. Frizzera F, de Freitas RM, Muñoz-Chávez OF, Cabral G, Shibli JA, Marcantonio E Jr. Impact of soft tissue grafts to reduce peri-implant alterations after immediate implant placement and provisionalization in compromised sockets. Int J Periodontics Restorative Dent. 2019 May/Jun;39(3):381-9. https://doi.org/10.11607/prd.3224

10. Froum SJ, Khouly I. Survival rates and bone and soft tissue level changes around one-piece dental implants placed with a flapless or flap protocol: 8.5-year results. Int J Periodontics Restorative Dent. 2017 May/Jun;37(3):327-37. https://doi.org/10.11607/prd.3073

11. Hutton CG, Johnson GK, Barwacz CA, Allareddy V, Avila-Ortiz G. Comparison of two different surgical approaches to increase peri-implant mucosal thickness: A randomized controlled clinical trial. J Periodontol. 2018 Jul;89(7):807-14. https://doi.org/10.1002/JPER.17-0597

12. Burkhardt R, Joss A, Lang NP. Soft tissue dehiscence coverage around endosseous implants: a prospective cohort study. Clin Oral Implants Res. 2008 May;19(5):451-7. https://doi.org/10.1111/j.1600-0501.2007.01497.x

13. Zucchelli G, Felice P, Mazzotti C, Marzadori M, Mounssif I, Monaco C, et al. 5-year outcomes after coverage of soft tissue dehiscence around single implants: a prospective cohort study. Eur J Oral Implantol. 2018;11(2):215-24.

14. Fürhauser R, Florescu D, Benesch T, Haas R, Mailath G, Watzek G. Evaluation of soft tissue around single-tooth implant crowns: the pink esthetic score. Clin Oral Implants Res. 2005 Dec;16(6):639-44. https://doi.org/10.1111/i.1600-0501.2005.01193.x

15. Belser UC, Grütter L, Vailati F, Bornstein MM, Weber HP, Buser D. Outcome evaluation of early placed maxillary anterior single-tooth implants using objective esthetic criteria: a cross-sectional, retrospective study in 45 patients with a 2 - to 4 -year follow-up using pink and white esthetic scores. J Periodontol. 2009 Jan;80(1):140-51. https://doi.org/10.1902/jop.2009.080435

16. Araújo MG, Silva JC, Mendonça AF, Lindhe J. Ridge alterations following grafting of fresh extraction sockets in man. A randomized clinical trial. Clin Oral Implants Res. 2015 Apr;26(4):407-12. https://doi.org/10.1111/clr.12366

17. Cosgarea R, Gasparik C, Dudea D, Culic B, Dannewitz B, Sculean A. Peri-implant soft tissue colour around titanium and zirconia abutments: a prospective randomized controlled clinical study. Clin Oral Implants Res. 2015 May;26(5):537-44. https://doi.org/10.1111/clr.12440

18. Wessels R, De Roose S, De Bruyckere T, Eghbali A, Jacquet W, De Rouck T, et al. The mucosal scarring Index: reliability of a new composite index for assessing scarring following oral surgery. Clin Oral Investig. 2019 Mar;23(3):1209-15. https://doi.org/10.1007/s00784-018-2535-6

19. Lindhe J, Araújo MG, Bufler M, Lilienberg B. Biphasic alloplastic graft used to preserve the dimension of the edentulous ridge: an experimental study in the dog. Clin Oral Implants Res. 2013 Oct;24(10):1158-63. https://doi.org/10.1111/j.1600-0501.2012.02527.x

20. Cha JK, Sanz M, Jung UW. Human autopsy study of peri-implant dehiscence defects with guided bone regeneration: a case report. Int J Periodontics Restorative Dent. 2018 Jun. https://doi.org/10.11607/prd.3329

21. Frost NA, Mealey BL, Jones AA, Huynh-Ba G. Periodontal biotype: gingival thickness as it relates to probe visibility and buccal plate thickness. J Periodontol. 2015 Oct;86(10):1141-9. https://doi.org/10.1902/jop.2015.140394

22. Jung RE, Sailer I, Hämmerle CH, Attin T, Schmidlin P. In vitro color changes of soft tissues caused by restorative materials. Int J Periodontics Restorative Dent. 2007 Jun;27(3):251-7.

23. Eghbali A, Seyssens L, De Bruyckere T, Younes F, Cleymaet R, Cosyn J. A 5-year prospective study on the clinical and aesthetic outcomes of alveolar ridge preservation and connective tissue graft at the buccal aspect of single implants. J Clin Periodontol. 2018 Dec;45(12):1475-84. https://doi.org/10.1111/jcpe.13018

24. Girbés-Ballester P, Viña-Almunia J, Peñarrocha-Oltra D, Peñarrocha-Diago M. Soft tissue response in posterior teeth adjacent to interdental single implants: a controlled randomized clinical trial comparing intrasulcular vs trapezoidal incision. Int J Oral Maxillofac Implants. 2016 May-Jun;31(3):631-41. https://doi.org/10.11607/jomi.4178

25. Negi R, Gupta R, Dahiya P, Kumar M, Bansal V, Kaur Samlok J. Ceramic soft tissue trimming bur: A new tool for gingival depigmentation. J Oral Biol Craniofac Res. 2019 Jan-Mar;9(1):14-8. https://doi.org/10.1016/j.jobcr.2018.07.002

26. Bengazi F, Wennström JL, Lekholm U. Recession of the soft tissue margin at oral implants. A 2-year longitudinal prospective study. Clin Oral Implants Res. 1996 Dec;7(4):303-10. https://doi.org/10.1034/j.1600-0501.1996.070401.x

27. Berglundh T, Armitage G, Araujo MG, Avila-Ortiz G, Blanco J, Camargo PM, et al. Peri-implant diseases and conditions: Consensus report of workgroup 4 of the 2017 World Workshop on the Classification of Periodontal and Peri-Implant Diseases and Conditions. J Periodontol. 2018 Jun;89 Suppl 1:S313-8. https://doi.org/10.1002/JPER.17-0739

28. Cooper LF, Reside G, Stanford C, Barwacz C, Feine J, Nader SA, et al. Three-year prospective randomized comparative assessment of anterior maxillary single implants with different abutment interfaces. Int J Oral Maxillofac Implants. 2019 Jan/Feb;34(1):150-8. https://doi.org/10.11607/jomi.6810 
29. Lin GH, Chan HL, Wang HL. The significance of keratinized mucosa on implant health: a systematic review. J Periodontol. 2013 Dec;84(12):1755-67. https://doi.org/10.1902/jop.2013.120688

30. Park WB, Kang KL, Han JY. Long-term clinical and radiographic observation of periimplant tissues after autogenous soft tissue grafts: a 15 -year retrospective study. Implant Dent. 2017 Oct;26(5):762-9. https://doi.org/10.1097/ID.0000000000000656

31. Sanz M, Lindhe J, Alcaraz J, Sanz-Sanchez I, Cecchinato D. The effect of placing a bone replacement graft in the gap at immediately placed implants: a randomized clinical trial. Clin Oral Implants Res. 2017 Aug;28(8):902-10. https://doi.org/10.1111/clr.12896

32. Jung RE, loannidis A, Hämmerle CH, Thoma DS. Alveolar ridge preservation in the esthetic zone. Periodontol 2000. 2018 Jun;77(1):165-75. https://doi.org/10.1111/prd.12209

33. Kan JY, Rungcharassaeng K, Deflorian M, Weinstein T, Wang HL, Testori T. Immediate implant placement and provisionalization of maxillary anterior single implants. Periodontol 2000. 2018 Jun;77(1):197-212. https://doi.org/10.1111/prd.12212

34. Kan JY, Rungcharassaeng K, Lozada J. Immediate placement and provisionalization of maxillary anterior single implants: 1 -year prospective study. Int J Oral Maxillofac Implants. 2003 Jan-Feb;18(1):31-9.

35. Kan JY, Rungcharassaeng K, Lozada JL, Zimmerman G. Facial gingival tissue stability following immediate placement and provisionalization of maxillary anterior single implants: a 2- to 8-year follow-up. Int J Oral Maxillofac Implants. 2011 Jan-Feb;26(1):179-87.

36. Veltri M, Ekestubbe A, Abrahamsson I, Wennström JL. Three-dimensional buccal bone anatomy and aesthetic outcome of single dental implants replacing maxillary incisors. Clin Oral Implants Res. 2016 Aug;27(8):956-63. https://doi.org/10.1111/clr.12664

37. Berglundh T, Lindhe J, Ericsson I, Marinello CP, Liljenberg B, Thomsen P. The soft tissue barrier at implants and teeth. Clin Oral Implants Res. 1991 Apr-Jun;2(2):81-90. https://doi.org/10.1034/j.1600-0501.1991.020206.x

38. Zucchelli G, Mazzotti C, Mounssif I, Mele M, Stefanini M, Montebugnoli L. A novel surgical-prosthetic approach for soft tissue dehiscence coverage around single implant. Clin Oral Implants Res. 2013 Sep;24(9):957-62. PMID:22924841

39. Anderson LE, Inglehart MR, El-Kholy K, Eber R, Wang HL. Implant associated soft tissue defects in the anterior maxilla: a randomized control trial comparing subepithelial connective tissue graft and acellular dermal matrix allograft. Implant Dent. 2014 Aug;23(4):416-25. https://doi.org/10.1097/ID.0000000000000122

40. Shibli JA, d'avila S, Marcantonio E Jr. Connective tissue graft to correct peri-implant soft tissue margin: a clinical report. J Prosthet Dent. 2004 Feb;91(2):119-22. https://doi.org/10.1016/i.prosdent.2003.09.017

41. Roccuzzo M, Dalmasso P, Pittoni D, Roccuzzo A. Treatment of buccal soft tissue dehiscence around single implant: 5 -year results from a prospective study. Clin Oral Investig. 2019 Apr;23(4):1977-83. https://doi.org/10.1007/s00784-018-2634-4

42. Sculean A, Mihatovic I, Shirakata Y, Bosshardt DD, Schwarz F, Iglhaut G. Healing of localized gingival recessions treated with coronally advanced flap alone or combined with either a resorbable collagen matrix or subepithelial connective tissue graft. A preclinical study. Clin Oral Investig. 2015 May;19(4):903-9. https://doi.org/10.1007/s00784-014-1299-x

43. Zucchelli G, De Sanctis M. Treatment of multiple recession-type defects in patients with esthetic demands. J Periodontol. 2000 Sep;71(9):1506-14. https://doi.org/10.1902/jop.2000.71.9.1506

44. Kurien T, Deo V, Bhati A. The pouch and tunnel technique for the management of adjacent gingival recession defects: surgical correction and one-year follow-up. J Contemp Dent Pract. 2010 Oct;11(5):041-8.

45. Langer B, Langer L. Subepithelial connective tissue graft technique for root coverage. J Periodontol. 1985 Dec;56(12):715-20. https://doi.org/10.1902/jop.1985.56.12.715

46. Urban IA, Klokkevold PR, Takei HH. Abutment-Supported Papilla: A Combined Surgical and Prosthetic Approach to Papilla Reformation. Int J Periodontics Restorative Dent. 2016 Sep-Oct;36(5):665-71. https://doi.org/10.11607/prd.2817

47. Jemt T. Regeneration of gingival papillae after single-implant treatment. Int J Periodontics Restorative Dent. 1997 Aug;17(4):326-33.

48. Tarnow DP, Magner AW, Fletcher P. The effect of the distance from the contact point to the crest of bone on the presence or absence of the interproximal dental papilla. J Periodontol. 1992 Dec;63(12):995-6. https://doi.org/10.1902/jop.1992.63.12.995

49. Salama H, Salama MA, Garber D, Adar P. The interproximal height of bone: a guidepost to predictable aesthetic strategies and soft tissue contours in anterior tooth replacement. Pract Periodontics Aesthet Dent. 1998 Nov-Dec;10(9):1131-41.

50. Tarnow D, Elian N, Fletcher P, Froum S, Magner A, Cho SC, et al. Vertical distance from the crest of bone to the height of the interproximal papilla between adjacent implants. J Periodontol. 2003 Dec;74(12):1785-8. https://doi.org/10.1902/jop.2003.74.12.1785

51. Feuillet D, Keller JF, Agossa K. Interproximal tunneling with a customized connective tissue graft: a microsurgical technique for interdental papilla reconstruction. Int J Periodontics Restorative Dent. 2018 Nov/Dec;38(6):833-9. https://doi.org/10.11607/prd.3549

52. Nemcovsky CE, Moses O, Artzi Z. Interproximal papillae reconstruction in maxillary implants. J Periodontol. 2000 Feb;71(2):308-14. https://doi.org/10.1902/jop.2000.71.2.308

53. Frizzera F, Tonetto M, Cabral G, Shibli JA, Marcantonio E Jr. Periodontics, implantology, and prosthodontics integrated: the zenith-driven rehabilitation. Case Rep Dent. 2017;2017:1070292. https://doi.org/10.1155/2017/1070292

54. Shapiro A. Regeneration of interdental papillae using periodic curettage. Int J Periodontics Restorative Dent. 1985;5(5):26-33.

55. Cirelli JA, Cirelli CC, Holzhausen M, Martins LP, Brandão CH. Combined periodontal, orthodontic, and restorative treatment of pathologic migration of anterior teeth: a case report. Int J Periodontics Restorative Dent. 2006 Oct;26(5):501-6. 
56. Geurs NC, Romanos AH, Vassilopoulos PJ, Reddy MS. Efficacy of micronized acellular dermal graft for use in interproximal papillae regeneration. Int J Periodontics Restorative Dent. 2012 Feb;32(1):49-58.

57. Wittneben JG, Buser D, Belser UC, Brägger U. Peri-implant soft tissue conditioning with provisional restorations in the esthetic zone: the dynamic compression technique. Int J Periodontics Restorative Dent. 2013 Jul-Aug;33(4):447-55. https://doi.org/10.11607/prd.1268

58. Frizzera F, Pigossi SC, Tonetto MR, Kabbach W, Marcantonio E Jr. Predictable interproximal tissue removal with a surgical stent. J Prosthet Dent. 2014 Oct;112(4):727-30. https://doi.org/10.1016/i.prosdent.2014.05.022

59. Lee WP, Seo YS, Kim HJ, Yu SJ, Kim BO. The association between radiographic embrasure morphology and interdental papilla reconstruction using injectable hyaluronic acid gel. J Periodontal Implant Sci. 2016 Aug;46(4):277-87. https://doi.org/10.5051/ipis.2016.46.4.277

60. Awartani FA, Tatakis DN. Interdental papilla loss: treatment by hyaluronic acid gel injection: a case series. Clin Oral Investig. 2016 Sep;20(7):1775-80. https://doi.org/10.1007/s00784-015-1677-z

61. Bertl K, Gotfredsen K, Jensen SS, Bruckmann C, Stavropoulos A. Can hyaluronan injections augment deficient papillae at implantsupported crowns in the anterior maxilla? A randomized controlled clinical trial with 6 months follow-up. Clin Oral Implants Res. 2017 Sep;28(9):1054-61. https://doi.org/10.1111/clr.12917

62. Korayem M, Flores-Mir C, Nassar U, Olfert K. Implant site development by orthodontic extrusion. A systematic review. Angle Orthod. 2008 Jul;78(4):752-60. https://doi.org/10.2319/0003-3219(2008)078[0752:ISDBOE]2.0.CO;2

63. Buskin R, Castellon P, Hochstedler JL. Orthodontic extrusion and orthodontic extraction in preprosthetic treatment using implant therapy. Pract Periodontics Aesthet Dent. 2000 Mar;12(2):213-9.

64. Ribeiro FV, Hirata DY, Reis AF, Santos VR, Miranda TS, Faveri M, et al. Open-flap versus flapless esthetic crown lengthening: 12-month clinical outcomes of a randomized controlled clinical trial. J Periodontol. 2014 Apr;85(4):536-44. https://doi.org/10.1902/jop.2013.130145

65. Verdugo F, Uribarri A, D’Addona A. Autogenous bone block grafting provides facial implant tissue stability long-term. Clin Implant Dent Relat Res. 2017 Jun;19(3):478-85. https://doi.org/10.1111/cid.12476

66. Keeve PL, Khoury F. Long-term results of peri-implant conditions in periodontally compromised patients following lateral bone augmentation. Int J Oral Maxillofac Implants. 2017 Jan/Feb;32(1):137-46. https://doi.org/10.11607/jomi.4880

67. De Boever AL, De Boever JA. Guided bone regeneration around non-submerged implants in narrow alveolar ridges: a prospective longterm clinical study. Clin Oral Implants Res. 2005 Oct;16(5):549-56. https://doi.org/10.1111/j.1600-0501.2005.01154.x

68. Dahlin C, Simion M, Hatano N. Long-term follow-up on soft and hard tissue levels following guided bone regeneration treatment in combination with a xenogeneic filling material: a 5-year prospective clinical study. Clin Implant Dent Relat Res. 2010 Dec;12(4):263-70. https://doi.org/10.1111/j.1708-8208.2009.00163.x

69. Schmitt CM, Moest T, Lutz R, Neukam FW, Schlegel KA. Anorganic bovine bone (ABB) vs. autologous bone (AB) plus ABB in maxillary sinus grafting. A prospective non-randomized clinical and histomorphometrical trial. Clin Oral Implants Res. 2015 Sep;26(9):1043-50. https://doi.org/10.1111/clr.12396

70. Bassir SH, Alhareky M, Wangsrimongkol B, Jia Y, Karimbux N. Systematic review and meta-analysis of hard tissue outcomes of alveolar ridge preservation. Int J Oral Maxillofac Implants. 2018 Sep/Oct;33(5):979-94. https://doi.org/10.11607/jomi.6399

71. Jensen SS, Bosshardt DD, Gruber R, Buser D. Long-term stability of contour augmentation in the esthetic zone: histologic and histomorphometric evaluation of 12 human biopsies 14 to 80 months after augmentation. J Periodontol. 2014 Nov;85(11):1549-56. https://doi.org/10.1902/jop.2014.140182

72. Mordenfeld A, Aludden H, Starch-Jensen T. Lateral ridge augmentation with two different ratios of deproteinized bovine bone and autogenous bone: a 2-year follow-up of a randomized and controlled trial. Clin Implant Dent Relat Res. 2017 Oct;19(5):884-94. https://doi.org/10.1111/cid.12512

73. Cosyn J, Sabzevar MM, De Bruyn H. Predictors of inter-proximal and midfacial recession following single implant treatment in the anterior maxilla: a multivariate analysis. J Clin Periodontol. 2012 Sep;39(9):895-903. https://doi.org/10.1111/j.1600-051X.2012.01921.x

74. loannidis A, Cathomen E, Jung RE, Fehmer V, Hüsler J, Thoma DS. Discoloration of the mucosa caused by different restorative materials - a spectrophotometric in vitro study. Clin Oral Implants Res. 2017 Sep;28(9):1133-8. https://doi.org/10.1111/clr.12928

75. Jung RE, Heitz-Mayfield L, Schwarz F. Evidence-based knowledge on the aesthetics and maintenance of peri-implant soft tissues: Osteology Foundation Consensus Report Part 3-Aesthetics of peri-implant soft tissues. Clin Oral Implants Res. 2018 Mar;29 Suppl 15:14-7. https://doi.org/10.1111/clr.13113

76. Isler SC, Uraz A, Kaymaz O, Cetiner D. An Evaluation of the relationship between peri-implant soft tissue biotype and the severity of periimplantitis: a cross-sectional study. Int J Oral Maxillofac Implants. 2019 Jan/Feb;34(1):187-96. https://doi.org/10.11607/jomi.6958

77. Schwarz F, Hegewald A, John G, Sahm N, Becker J. Four-year follow-up of combined surgical therapy of advanced peri-implantitis evaluating two methods of surface decontamination. J Clin Periodontol. 2013 Oct;40(10):962-7. https://doi.org/10.1111/icpe.12143 
78. Thoma DS, Zeltner M, Hilbe M, Hämmerle CH, Hüsler J, Jung RE. Randomized controlled clinical study evaluating effectiveness and safety of a volume-stable collagen matrix compared to autogenous connective tissue grafts for soft tissue augmentation at implant sites. J Clin Periodontol. 2016 Oct;43(10):874-85. https://doi.org/10.1111/icpe.12588

79. Thoma DS, Naenni N, Benic GI, Hämmerle CH, Jung RE. Soft tissue volume augmentation at dental implant sites using a volume stable three-dimensional collagen matrix - histological outcomes of a preclinical study. J Clin Periodontol. 2017 Feb;44(2):185-94. https://doi.org/10.1111/icpe.12635

80. Huber S, Zeltner M, Hämmerle CH, Jung RE, Thoma DS. Non-interventional 1-year follow-up study of peri-implant soft tissues following previous soft tissue augmentation and crown insertion in single-tooth gaps. J Clin Periodontol. 2018 Apr;45(4):504-12. https://doi.org/10.1111/icpe.12865

81. Rojo E, Stroppa G, Sanz-Martin I, Gonzalez-Martín O, Alemany AS, Nart J. Soft tissue volume gain around dental implants using autogenous subepithelial connective tissue grafts harvested from the lateral palate or tuberosity area. A randomized controlled clinical study. J Clin Periodontol. 2018 Apr;45(4):495-503. https://doi.org/10.1111/icpe.12869

82. Amin PN, Bissada NF, Ricchetti PA, Silva AP, Demko CA. Tuberosity versus palatal donor sites for soft tissue grafting: asplit-mouth clinical study. Quintessence Int. 2018;49(7):589-98. PMID:29881832

83. Barone A, Toti P, Marconcini S, Derchi G, Saverio M, Covani U. Esthetic outcome of implants placed in fresh extraction sockets by clinicians with or without experience: a medium-term retrospective evaluation. Int J Oral Maxillofac Implants. 2016 Nov/ Dec;31(6):1397-406. https://doi.org/10.11607/jomi.4646

84. Viana PC, Kovacs Z, Correia A. Purpose of esthetic risk assessment in prosthetic rehabilitations with gingiva-shade ceramics. Int J Esthet Dent. 2014;9(4):480-9.

85. Frizzera F, Shibli JA. Marcantonio Jr. Estética integrada em periodontia e implantodontia. Nova Odessa: Quintessence; 2018. 